\section{Concerning: Gesemann M, et al.: Association of Erythropoiesis during Autologous Blood Donation with Initial Hemoglobin Concentration and Length of Donation Period. Infusionsther Transfusionsmed 1999;26:353-359.}

The above-mentioned paper requires a few comments:

1) The statement 'blood loss and borderline anemia resulted in increases of erythropoietin concentrations which exceeded the physiological range by less than factor 7 ...' is misleading. Physiological concentrations of erythropoietin (EPO) range from 11 to $31 \mathrm{U} / \mathrm{ml}$ (5-95 percentile) [1]. The highest EPO levels presented in the study (day 21, prior to 4th donation) were $43 \pm 14 \mathrm{mU} / \mathrm{ml}$ in men and $43 \pm 23$ $\mathrm{mU} / \mathrm{ml}$ in women. These concentrations were only moderately above the physiological range and by no means close to factor 7. Such a moderate increase of erythropoietin serum concentration prior to each donation had been reported previously [2].

2) The EPO concentration prior to each autologous donation does not properly reflect the response of serum EPO to phlebotomy. EPO concentrations after autologous donation show a biphasic pattern: A peak concentration on the first day after phlebotomy is followed by a plateau phase at a lower but still elevated level [3, 4].

3) Total red blood cell volume should be calculated correcting large-vessel hematocrit to total-body hematocrit [5].

4) On the basis of the formula of Nadler et al. [6], the total red blood cell volume and the volume of red blood cells regenerated during the donation period may be underestimated. In chronically anemic patients blood volume may be greater than in patients with hemoglobin concentrations in the normal range [7]. This should at least be discussed.

5) Calculation of the net gain of erythrocytes should take into account that erythrocytes are lost during the production of buffy coat-poor packed red blood cells and during storage. These losses may well amount to more than $10 \%$ of the red blood cells initially collected.

\section{A. Lorentz, Mannheim}

\section{References}

1 Eckardt KU, Kurtz A, Hirth P, Scigalla P, Wieczorek L, Bauer CH: Evaluation of the stability of human erythropoietin in samples for radioimmunoassay. Klin Wochenschr 1988;66:241-245.

2 Kickler MS, Spivak JL: Effect of repeated whole blood donations on serum immunoreactive erythropoietin levels in autologous donors. JAMA 1988;260:65-67.
3 Lorentz A, Jendrissek A, Eckardt KU, Schipplick M, Osswald PM, Kurtz A: Serial immunoreactive erythropoietin levels in autologous blood donors. Transfusion 1991:31:650-654.

4 Lorentz A, Eckardt KU, Osswald PM, Duchow JR: Erythropoietin levels in patients depositing autologous blood in short intervals. Ann Hematol 1992;64 281-285.

5 Najean Y, Deschrywer F: The body/venous haematocrit ratio and its use for calculating total blood volume from fractional volumes. Eur J Nucl Med 1984 9:558-560.

6 Nadler SB, Hidalgo JU, Bloch T: Prediction of blood volume in normal human adults. Surgery 1962;51:224-232.

7 Gabutti V, Piga A, Fortina P, Miniero R, Nicola P: Correlation between transfusion requirement, blood volume and haemoglobin level in homozygous beta-thalassaemia. Acta Haematol 1980;64:103-108.

\section{Author's Reply}

We appreciate the comments by A. Lorentz encouraging us to discuss our findings in greater detail.

Concerning comments 1 and 2:

The aim of our study was not to describe the physiological erythropoietin (EPO) response to blood loss, but we rather sought for an indicator of erythropoiesis. Therefore, the EPO levels obtained during the plateau phase before the days of donation - even after a decline [1] - seemed more suitable than a short-lived increase of EPO levels to reflect blood lossinduced effects.

In our study EPO levels reached a maximum of $85 \mathrm{U} / 1$. We agree with A. Lorentz that the statement '... less than factor 7' was vague in that individual increases less than 7 -fold were observed; however, the physiological range is not clearly defined. Normal EPO ranges other than 11-31 U/1 as published by Lorentz et al. [1] are 4-26 U/1 [2] and, as an approximation, 10-20 U/1 [3] and coincide with our baseline EPO concentrations before the first donation (men $18 \pm 6.2 \mathrm{U} / 1$, women $13 \pm$ 5.2 U/l). (The paper of Eckhardt et al. [4] cited by A. Lorentz does not state a physiological EPO range.)

Concerning comments 3 and 4:

We are aware that our calculations of total red blood cell (RBC) volumes are indirect measurements utilizing body weight, height and hematocrit. Since body weight and height were assumed as being constant over 5 weeks, hematocrit was the only parameter to influence calculations of RBC volume. Our findings are mainly based on changes of hematocrit and hemoglobin. Therefore, total body RBC volumes as an absolute measure were of minor importance. Furthermore, the equations developed by Nadler et al. [5] which were utilized for our calculations already include a correction factor of 0.91 for the venous/body hematocrit ratio. Thus this factor was already included in our calculations. Finally, Najean and De-

\section{KARGER}

Fax +497614520714

(C) 2000 S. Karger GmbH, Freiburg

E-mail Information@Karger.de www.karger.com/journals/iut

www.karger.com 
schrywer [6] stated that the small variation of '... results around the mean value makes the potential error very low ... in polycythaemic and normal subjects'.

In their publication on transfused patients with homozygous beta-thalassemia Gabutti et al. [7] stated that, with a hemoglobin level '... above $12 \mathrm{~g} / \mathrm{dl}$, the blood volume is nearly normal'. The donors included in our study had no thalassemia, were neither chronically anemic, nor transfused, most of them had hemoglobin concentrations above $12 \mathrm{~g} / \mathrm{dl}$ and were therefore regarded as normal subjects in whom only minor differences between calculated and true hemoglobin concentrations were to be expected.

Concerning comment 5:

A. Lorentz correctly points out that approximately $50 \mathrm{ml}$ of buffy coat $(10 \%)$ is lost during separation of $500 \mathrm{ml}$ whole blood in an RBC concentrate and plasma. The partial loss of erythrocyte viability during storage was also disregarded in our study. However, both factors pertain to the availability of donated RBCs at surgery, and were not an objective of our study. Instead, the purpose was to describe the balance between blood donation and $\mathrm{RBC}$ regeneration.
These comments on EPO concentrations, total body RBC volume, and the net gain of autologous blood donation leave our findings unchanged that high initial hemoglobin concentrations and long time intervals between donations and surgery support the regeneration of RBCs.

M. Gesemann, Idar-Oberstein

\section{References}

1 Lorentz A, Jendrissek A, Eckardt KU, Schipplick M, Osswald PM, Kurtz A: Serial immunoreactive erythropoietin levels in autologous blood donors. Transfusion 1991;31:650-654.

2 Kickler TS, Spivak JL: Effect of repeated whole blood donations on serum immunoreactive erythropoietin levels in autologous donors. JAMA 1988;260:65-67.

3 Erslev AJ: Erythropoietin. N Engl J Med 1991;324:1339-1344.

4 Eckardt KU, Kurtz A, Hirth P, Scigalla P, Wieczorek L, Bauer C: Evaluation of the stability of human erythropoietin in samples for radioimmunoassay. Klin Wochenschr 1988;66:241-245.

5 Nadler SB, Hidalgo JU, Bloch T: Prediction of blood volume in normal adults. Surgery 1962;51:224-232.

6 Najean Y, Deschrywer F: The body/venous haematocrit ratio and its use for calculating total blood volume from fractional volumes. Eur J Nucl Med 1984;9:558-560.

7 Gabutti V, Piga A, Fortina P, Miniero R, Nicola P: Correlation between transfusion requirement, blood volume and haemoglobin level in homozygous beta-thalassaemia. Acta Haematol 1980;64:102-108.

\section{Das Transfusionsgesetz und die neuen Richtlinien}

\section{MAGDEBURGER FORUM FÜR FREMDBLUTSPARENDE MASSNAHMEN 23./24. Juni 2000}

\section{WER setzt WIE die geforderten Vorgaben zur Qualitätssicherung um? \\ Wie kann das Transfusionsgesetz (TFG) zum rationalen Einsatz von Blutprodukten beitragen?}

Themen:

1. Aufgaben der Transfusionsverantwortlichen und -beauftragten - Tipps zur praktischen Umsetzung der notwendigen Maßnahmen

2. Anleitung zur Erstellung von transfusionsmedizinischen Dienstanweisungen mit Beispielen

3. Rationaler Einsatz von Blut und Plasmaprodukten nach den Richtlinien der BÄK

4. Reduzierung des Fremdblutverbrauchs durch qualitätssichernde Maßnahmen

5. Einflußnahme auf die Qualität durch die Transfusionskommission (Themen-Checkliste)

Stichtag für die «Qualitätssicherung» gemäß § 15 TFG ist der 07.Juli 2000 mit der gesetzlichen Übertragung von Verantwortlichkeiten.

Wissenschaftliche Leitung: Prof. Dr. Marcell U. Heim, Dr. Ilona Wojtzyk Otto-von-Guericke-Universität Magdeburg, Institut für Transfusionsmedizin und Immunhämatologie mit Blutbank, Leipziger Straße 44, D-39120 Magdeburg Tel. +49 39167 13-700, Fax -747

Tagungsort: Herrenkrug Parkhotel Magdeburg

Organisation: Porstmann Kongresse $\mathrm{GmbH}$, Friedrichstraße 130 a, D-10117 Berlin

Tel. +49 302844 99-0, Fax -11

E-mail porstmann@porstmann-kongresse.de 